\title{
Cancer Stem Cells or Tumor Survival Cells?
}

\author{
Yang D. Teng,,-3 Lei Wang, ${ }^{1-3}$ Serdar Kabatas, ${ }^{1-3}$ Henning Ulrich,, and Ross D. Zafonte ${ }^{1}$
}

Research endeavors originally generated stem cell definitions for the purpose of describing normally sustainable developmental and tissue turnover processes in various species, including humans. The notion of investigating cells that possess a vague capacity of "stamm (phylum)" can be traced back to the late 19th century, mainly concentrating on cells that could produce the germline or the entire blood system. Lately, such undertakings have been recapitulated for oncogenesis, tumor growth, and cancer cell resistance to oncolytic therapies. However, due to the complexity and basic life-origin mechanisms comprising the genetic and epigenetic repertoire of the stemness in every developing or growing cell, presently there are ongoing debates regarding the biological essentials of the stem cell-like tumor initiation cells (ie, cancer stem cells; CSCs). This conceptual analysis focuses on the potential pitfalls of extrapolating that CSCs bear major traits of stemness. We propose a novel nomenclature of Tumor Survival Cells (TSCs) to further define tumor cells behaving like CSCs, based on the ruthless and detrimental features of Cancer Cell Survivology that appears fundamentally different from stem cell biology. Hence, precise academic separation of TSCs from all the stem cell-related labels applied to these unique tumor cells may help to improve scientific reasoning and strategies to decode the desperado-like survival behaviors of TSCs to eventually overcome cancer.

Keywords: cancer stem cell, tumor survival cell, cancer cell survivology, dedifferentiation, stem cell, stemness

\section{Background}

E RNST HAECKEL (1834-1919), a German biologist, physician, naturalist, artist, and philosopher, is considered a pioneer in developmental cell biology research. He proposed the nomenclature of "Stammzellen" (stem cells) in his published lectures on "Natürliche Schöpfungsgeschichte", (1868) for unicellular organisms or protozoa that he thought to be the phylogenetic ancestors of multicellular organisms [1]. He considered that the name stem cell seemed to be the most explicit and appropriate one for a pluripotent cell phenotype, from which all other cells stem. They are, in the most literal sense, the stem father and the stem mother of all the infinitive generations of cells that the multicellular organism is ultimately built with [1]. The term was created to distinguish the unique profile of the fertilized egg cell from the original egg cell. Following the doctrine, the human stem cell directly represented the whole future child $[2,3]$.

Haeckel's neologism was derived from the metaphorical language popularly used back then in medical and philosophical discussions about cells and the human body.
Scholars (eg, Rudolf Virchow: 1821-1902) often compared cells in a given organism with human individuals within an established state system [4]. For the first time, the concept of a stem cell defined cell state in a hierarchical and centralized format, departing from the previous conception of a liberal and relatively egalitarian profile. It is worth noticing that (1) stem cells are primordial biological entities destined to build a homeostatic system that can reproduce itself, and (2) the metaphorical implication of the stem cell concept not only has its general public education value, but more importantly, its usage deeply impacts the way scientists frame and orient their reasoning.

For example, at the turn of the 19th century, Artur Pappenheim (1870-1916), Alexander Maximow (1874-1928), Ernst Neumann (1798-1895), and other scholars proposed a progenitor cell-based theory for the common origin of all hematopoietic lineages. In the beginning of the 20th century, the advancements in the field of hematopoiesis and leukemia research further distinguished the stem cell definition, underscoring a common central capacity for self-renewal and phenotypic differentiation [2].

\footnotetext{
${ }^{1}$ Department of Physical Medicine and Rehabilitation, Harvard Medical School and Spaulding Rehabilitation Hospital Network, Brigham and Women's Hospital, and Massachusetts General Hospital, Boston, Massachusetts.

${ }^{2}$ Department of Neurosurgery, Harvard Medical School, Boston, Massachusetts.

${ }^{3}$ Division of SCI Research, VA Boston Healthcare System, Boston, Massachusetts.

${ }^{4}$ Departamento de Bioquímica, Instituto de Química, Universidade de São Paulo, São Paulo, Brazil.

(C) Yang D. Teng et al. 2018; Published by Mary Ann Liebert, Inc. This Open Access article is distributed under the terms of the Creative Commons License (http://creativecommons.org/licenses/by/4.0), which permits unrestricted use, distribution, and reproduction in any medium, provided the original work is properly cited.
} 


\section{The Evolving Theory of Cancer Stem Cells}

Possible underlying relations between embryonic stem cells (ESCs) and normal tissue or cancer-like neoplasm were also speculated in the late 19th century. The notion concerned the chances for development deviations of ESCs to contribute to malformation or tumorigenesis [5]. However, key components of this tumorigenic theory (eg, the displacement of embryonic cells) were questioned by gathering experimental evidence around World War II [6]. In the 1950s and early 1960s, systematical investigation of murine teratoma cells resulted in successful isolation of mouse ESCs and basic characterization techniques. The research progression further cultivated the postulation of existence of the so called cancer stem cells (CSCs) [7]. By the early 1980s, murine ESCs could be reliably isolated and maintained in vitro [8,9], which, together with the identification of human neural stem cell and human ESC lines laid down the foundation for opening the contemporary chapter of stem cell research [10-12].

In parallel, the concept of CSCs was gradually shaped out in the 1960s. For instance, Kleinsmith and Pierce demonstrated that donor embryonal carcinoma cells (ECCs) could give rise to both somatic tissue cells and ECCs [7]. It was reported that only $\sim 0.1 \%-1 \%$ of murine myeloma cells could give rise to new clones in vitro, and only $\sim 1 \%-4 \%$ of leukemia cells formed macroscopic colonies in the spleen after transplantation in nonobese diabetic/SCID (severe combined immune deficiency) mice [13]. Noticeably, the data showed certain similarities with the formation of nodules that was observed in the spleens of irradiated mice following administration of bone marrow cells. The number of nodules generated was found to be dose dependent on the quantity of the injected bone marrow cells. Thus, the investigators hypothesized that a single hematopoietic stem cell (ie, colony-forming unit) might be able to develop into a cell colony that gradually formed an individual nodule [14]. These findings combinatorially inferred the possibility that a limited number of tumor cells might have "stem celllike" oncological behavior and act as a ringleader for tumor initiation. Taken together, these discoveries promoted the establishment of the CSC theory.
By the mid-1970s, the clonal evolution theory of cancer growth was additionally enriched by uncovering that mutations in oncogenes and tumor suppressor genes played important roles in tumorigenesis [15]. Fearon and Vogelstein proposed that the stepwise acquisition of mutations in specific oncogenes was critical in the progression and malignization of early adenoma, based on their clonal evolution model of colon cancer [16]. The feature of colon cancers indeed exhibited a generally linear tumor evolution with incremental genetic mutations following inactivation of adenomatous polyposis coli as the most common gene mutation. Elucidating these genetic mechanisms helped to address the question of why a given malignant tumor lesion may contain a subpopulation of cells that show everescalating malignant behavior [16]. By contrast, breast cancers retain discernible levels of intratumoral heterogeneity [17]: for example, amplification of HER2 (human epidermal growth factor receptor 2), mutation of PIK3CA (phosphoinositide-3-kinase, catalytic, alpha polypeptide), etc. Moreover, similar heterogeneity exists in leukemia. Nearly all subtypes of acute myeloid leukemia (AML) can be implanted in immunodeficient mice by engraftment of a CD $34^{+} \mathrm{CD} 38^{-}$fraction of AML cells (ie, acute myelogenous leukemia stem cells, LSCs: 1/million AML cells) [18].

At the beginning of the 21st century, the concept of CSC or tumor stem cell was refined based on the evidence that certain developmental signaling pathways governing regular stem cells might also function in CSCs for tumor formation [19]. Therefore, CSCs, as a small subpopulation of tumor cells, were proposed as the primary force fueling oncogenesis and were characterized by their capability of infinite self-renewal and drug resistance [19]. For example, to initiate a new tumor in a mouse, only $\sim 100 \mathrm{CD} 44^{+} \mathrm{CD} 24^{-/ \text {low }}$ human breast cancer cells are required, indicating their potent cancerogenic potential relative to other phenotypes of tumor cells that fail to grow tumors even under thousandfold higher quantity [20]. The consensus definition of a CSC was first established by the participants of the 2006 American Association of Cancer Research Workshop on Cancer Stem

FIG. 1. Established molecular markers of TSCs (also called CSCs; left panel) and ESCs (right panel). In support to our hypothesis, TSCs possess genes either uniquely to themselves (markers in red zone and red font) or shared with ESCs (molecules in yellow zone) that are predominantly related to cell survival functions (eg, proliferation, migration, invasive growth, drug resistance, etc.; markers in red fonts). They play critical roles in cancer metastasis, reoccurrence, and oncolytic treatment failure. Although TSCs in different types of malignant tumors share numerous molecular markers with ESCs (markers in yellow zone), they are deficient in molecules that are essential for the maintenance of pluripotent status, selfrenew, and lineage-specific differentiation, key features of authentic stemness for physiological development and reproduction of biological organisms/entities, including humans (markers in green fonts). This unbalanced desperado-like survival strategy of TSCs disrupts homeostasis and exhausts resources essential for host life, which inevitably leads to demises of both host and tumor cells (left panel flowcharts). By contrast, totipotent stem cells, inner cell mass-derived ESCs, carry stemness genes mostly for physiological development (markers in green font and green zone) and keep an effective balance between cell development (markers in green font), tissue formation (eg, markers in yellow: for cell differentiation), and survival (markers in red font; note: functions of the marker molecule in black font are presently unclear). These genes work in consortium to drive proper cell proliferation and migration, lineage differentiation, organ genesis and systemic homeostasis, and to make the biological species sustainable. For example, human ESCs differentiate into progenitor cells of the three primary germ layers that subsequently establish functional tissues, organs, and systems. With a new embryo implantation and growth, the whole process of ESC-originated development results in a sustainable life circle for human race (right panel flowcharts). The process defines the authentic stemness capacity (ie, stamm or phylum). CSC, cancer stem cell; Drug Resi., drug resistance; ESC, embryonic stem cell; Gpj, gap junction; HSC, hematopoietic stem cell; MDR, multiple drug resistance; NSC, neural stem cell; PT, posttreatment; TSC, tumor survival cell. Color images available online at www.liebertpub.com/scd 

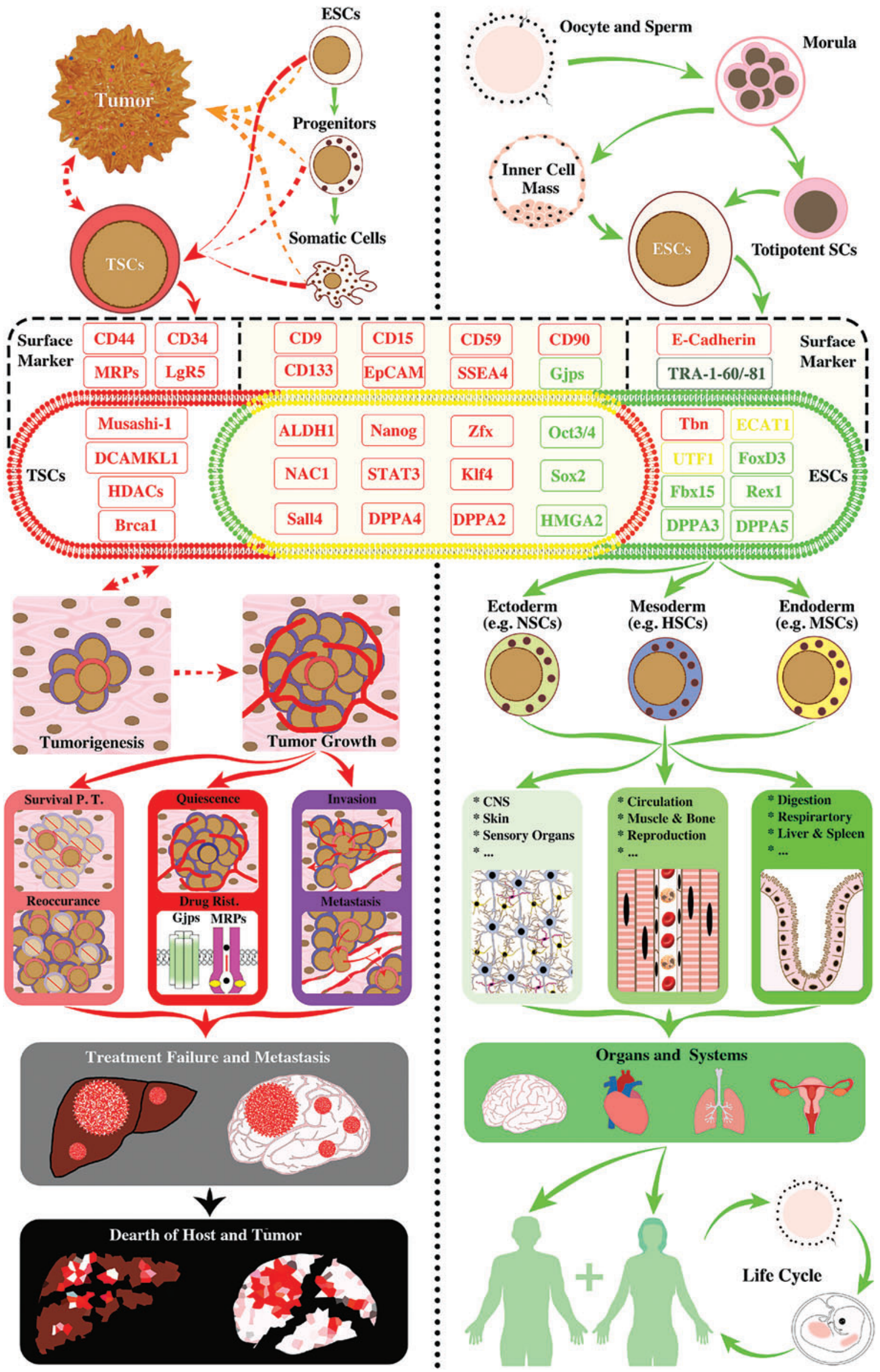
Cells. The definition states that CSCs should possess the properties of tumorigenicity, self-renewal capacity, continuous passage ability, multilineage differentiation potential to generate the heterogeneous subpopulations of cancer cells that comprise malignant tumors, and unique and reliable surface markers [20-23].

\section{Reciprocal Interaction Between CSC and Normal Stem Cell Research Studies}

The CSC theory, besides its academic impact, has practically revealed new therapeutic targets for designing specific therapies to treat cancer. To this end, knowledge gleaned from investigating normal stem cells has markedly improved the understanding of the heterogeneous nature of cancer cells $[19,23]$. It is believed that CSCs hold higher oncologic plasticity than regular cancer cells; this plasticity may be powered mainly by stemness-like capabilities, promoting efforts to identify key triggers of neoplasm occurrence/recurrence, metastasis, and drug resistance [19-25]. Therefore, it is pivotal to investigate whether or to which scale CSCs may genetically overlap with normal stem cells. Ultimate understanding of these mechanisms will facilitate therapeutic development for managing cancer.

Indeed, a subgroup of CSCs has been found to behave as tumor metastasis and recurrence (or drug resistance)-initiating cells due to their quiescent state, tumorigenicity, and migration capabilities. The cells express markers of epithelial mesenchymal transition (EMT), including collagen IV $\alpha 1$, $\alpha$-SMA, $\beta$-catenin, etc. [24]. EMT describes the process of the transdifferentiation of stationary epithelial cells into motile mesenchymal cells. Over EMT evolvement, epithelial cells lose their tight junctions and apical-basal polarity, reorganize their cytoskeleton, and experience changes in the signaling cascades that control cellular morphological features and gene expression programs. These alterations share main features of dedifferentiation, increasing the motility of individual cells, and enabling them to develop into phenotypes with invasive behaviors that are crucial for cell survival. EMT process can be regulated or influenced by multiple pathways that are activated by TGF- $\beta$, HGF, EGF, FGF, VEGF, Wnt, Shh, IL6, HIF1 $\alpha$, and other signaling molecules through SNAI1/Snail, ZEB1/ZEB2, and/or basic helix-loophelix proteins-mediated transcription activity [25]. EMT events are crucial in major biological courses of embryonic development, postnatal growth, tissue regeneration, lesion healing, and stem cell homeostasis. EMT-like mechanisms have also been implicated in triggering oncology of malignancies and pathophysiology of fibrosis [25]. The involvement of dedifferentiation as a stem cell-like feature (ie, stemness) in some cancer cells to drive tumorigenesis has been further validated by new findings published in The Pan-Cancer Atlas, the official data portal of The Cancer Genome Atlas (TCGA) consortium. Specifically, TCGA tumors' (ie, 11,000 tumors from 33 of the most prevalent forms of cancer) epigenetic and expressionbased stemness indices measured oncogenic dedifferentiation and revealed association with oncogenic dedifferentiation. The investigators reported that the dedifferentiated oncogenic phenotype was generally most prominent in metastatic tumors. The indices identified novel targets for designing potential therapies to augment tumor differentiation [26]. Importantly, it has been recognized that dedifferentiation is likely a mecha- nism for cell survival [27]. We, therefore, suggest to also focus on survival benefits that can be derived from the intratumor molecular heterogeneity determined by the stemness indices reported [26], to dissect it from classically defined stemness indices of developmental biology that emphasize differentiation [28].

\section{CSCs Do Not Possess Authentic Stemness Biology}

Researchers have determined a variety of surface markers for identifying CSCs. As examples, currently well-accepted markers for glioma CSCs include CD15, CD90, CD133, nestin, and integrin- $\alpha 6$. CD44, ALDH, CD117, CD133, and $\mathrm{CD} 24$ are utilized to profile ovarian CSCs. For malignant melanoma CSCs, ABCB5, ALDH1, CD20, CD133, and CD271 are commonly enlisted. ALDH1, CD44, CD24, CD90, and CD133 are highlighted as markers for breast CSCs. There are some shared CSC markers frequently expressed in different types of malignant tumors. Among them, CD133 appears to be the most common one, which coincidently is also a marker of normal stem cells (eg, undifferentiated ESCs, HSCs, and NSCs).

However, in spite of accumulation of published data that is in favor of the CSC concept, the validity of the stemness biology in CSCs has been constantly challenged by observations concerning discrepancies regarding the biological characteristic, phenotype, genetic profile, and subpopulation proportion ratio of the alleged "original" CSC. Studies showed that successful isolation rate of glioma CSCs was dependent on microenvironmental specifics, including cellcell interaction, culture medium composition, and cell incubation temperature $[29,30]$. The data begin to contest the existing CSC theory and arguably suggest that these cells could be a reactive dedifferentiation consequence of regular cancer cells driven by microenvironmental stress, attempting to maximize the survival probability of the tumor, rather than an outcome of a conventionally defined hierarchical cascade of tumor cell development. In fact, CSC-produced intratumor heterogeneity is incapable to form any truly sustainable biological system such as normal tissues or organs. The dedifferentiated tumor cells seemed to be destined to refill the pool of previous CSCs upon their depletion resulting from regular cancer cell differentiation, host immune counteraction, and/or anticancer treatment [31]. Thereby, we hypothesized that the commonly defined CSCs might mostly retain genes underlying cell survival (eg, dedifferentiation, proliferation/self-renewal, migration, engraftment, and drug resistance) relative to those of normal stem cells that fundamentally concern lineage-oriented differentiation, homeostasis, stemness, and sustainability through self-renewal and reproduction (Figs. 1 and 2 and Table 1). To test this hypothesis, we systematically examined a total of 50 established molecular markers of CSCs and/or ESCs. The results demonstrated that (1) CSC exclusive markers are genes that support cancer cell migration, metastasis and invasion, and/or enable drug resistance capability (see Figs. 1 and 2 for red markers) [32-42], and only two of them bear uncertain functions (gray markers: CD96 [43] and PSCA [44]; Fig. 2); (2) the majority of markers shared by CSCs and ESCs are genes that are also related to cell migration and metastasis or engraftment (see Figs. 1 and 2 for 


\begin{tabular}{|c|cc||c|}
\hline TSC Markers & \multicolumn{1}{c|}{ TSC and ESC Overlapping Markers } & ESC Markers \\
\hline CD34 [32] & CD9 [45] & CD90 [46] & E-Cadherin [69] \\
CD44 [33] & Integrin $0.6[47]$ & SSEA4 [33] & Tbn [70] \\
DCAMKL1 [34] & SSEA1 $($ CD15) [48] & Klf4 [49] & ECAT1 [71] \\
ABCB5 [35] & EpCAM [50] & FriR [51] & GCNF [72] \\
MRPs [36] & TDGF-1/Cripto [52] & CD59 [53] & UTF1 [73] \\
TIM3 [37] & ALDH1 [54] & SCF/SCFR $[55,56]$ & ECAT11 [74] \\
& NAC1 [57] & CD133 [58] & FoxD3 [75] \\
LgR5 [38] & SPPA4/DPPA2 [59] & Sall4 [60] & Fbx15 [76] \\
Musashi-1 [39] & Zfx [61] & STAT3 [62] & DPPA3 [77] \\
Brca1 [40] & SSEA3 [63] & Nanog [64] & DPPA5 [78,79] \\
HDACs [41,42] & HMGA2 [65] & GJA [66] & Rex1 [80] \\
CD96 [43] & Oct-3/-4 [67] & Sox2 [68] & TRA-1-60/-81 [81] \\
PSCA [44] & & &
\end{tabular}

FIG. 2. Common molecular markers of TSCs and ESCs. Color codes: (1) Green: genes related to self-renewal and maintenance of pluripotent status or dedifferentiation; (2) Yellow: genes important for cell differentiation; (3) Brown: genes that support cell survival and cell proliferation but are not essential for the maintenance of pluripotent status of cells; (4) Red: genes enabling cancer cell migration, metastasis and invasion, and/or drug resistance; (5) Gray: specific genetic markers that are presently unclear for their functions. Color images available online at www.liebertpub.com/scd

red markers $[42-59,61])[45-63]$, with one related to proliferation but not stemness (brown marker: stage-specific embryonic antigen-3; SSEA3; Fig. 2) [64], and a few concerning self-renewal and maintenance of pluripotent status or dedifferentiation (green markers: HMGA2 [65], GJA [66], Oct-3/-4 [67], and Sox [68]; Fig. 2); and (3) notably, of markers selective for ESCs, there are two molecules for cell migration and engraftment (red markers; Fig. 2) [69,70], three factors important for cell differentiation (yellow markers; Fig. 2) [71-73], and mostly, genes enabling selfrenewal and maintenance of pluripotent status or lineage differentiation (green markers; Fig. 2) [74-80], except for one gene with unclear function (gray marker: TRA-1-60/-81; Fig. 2) [81].

Therefore, the analytical outcome in general confirms our postulation. Although CSCs share many genetic markers with ESCs, deeper dissection revealed that CSC-specific genes are predominantly in charge of cell survival activities typically involving invasive growth, cell migration, and survival adaptation (eg, intratumoral heterogeneity and drug resistance), which jointly play critical roles in cancer metastasis, reoccurrence, and insensitivity to chemotherapy and host immune counteractions. By contrast, inner cell mass-derived ESCs exhibit a balanced profile between genes responsible for authentic stemness maintenance emphasizing pluripotency, self-renewal, capability of lineage-specific differentiation and development into reproducible organisms, and genes empowering cell homeostatic survival (Fig. 1; see detailed information in Table 1). Evidently, the biological trajectories of CSCs, which are hallmarked by unilateral attempts for self-survival at the expense of regular cancer and host cells, do not match natural paradigms of developmental biology-related stem cells. Normal stem cells, alongside their proliferation, migration, and differentiation, constantly build homeostasis with surrounding cells through their functional multipotency [82]; and once differentiated into terminal phenotypes, they will not dedifferentiate under physiological conditions.
In corroboration with our analysis, published experimental results clearly demonstrate that all colonies derived from randomly selected single cells of murine lung and breast cancer cell lines can form tumors following allografting in histocompatible mice [83]. A recent study reported that using an approach that integrated major immunogenomics methods (ie, total lymphocytic infiltrate assessed from genomic and haemotoxylin and eosin staining image data, immune cell fractions from deconvolution analysis of mRNA-sequencing data, immune gene expression signatures, neoantigen prediction, $\mathrm{T}$ cell receptor and $\mathrm{B}$ cell receptor repertoire inference, viral RNA expression, and somatic DNA alterations) to characterize the immune tumor microenvironment (TME) (ie, the immune subtype), investigators identified six immune subtypes that span TCGA cancer tissue types and molecular subtypes [84]. Cancer immune subtypes differ by somatic aberrations, TME, and survival, but not by differentiation. The six immune subtypes are wound healing, IFN- $\gamma$ dominant, inflammatory, lymphocyte depleted, immunologically quiet, and TGF- $\beta$ dominant, all being characterized by differences in macrophage or lymphocyte signatures, Th1:Th2 cell ratio, extent of intratumoral heterogeneity, aneuploidy, extent of neoantigen load, overall cell proliferation, expression of immunomodulatory genes, and prognosis [84]. Again, the heterogeneous features of tumor-immune cell interactions are mechanisms underlying cell survival, not sustainable development and organ genesis [85]. Interestingly, TME by definition contains the anatomically distinct regions defined as CSC niches that maintain CSCs by preserving their self-renewal, clonal tumor initiation capacity, and clonal long-term repopulation and metastatic potential, as well as by shielding them from immune surveillance [86]. It has been shown that cells within the CSC niches produce factors that stimulate CSC self-renewal, induce angiogenesis, regulate immune cells, and recruit other stromal cells that secrete additional factors to promote 
Table 1. Common Molecular Markers of Tumor Survival Cells and Embryonic Stem Cells and Their Functions

\begin{tabular}{|c|c|c|c|c|}
\hline Abbreviation & Full name & $\begin{array}{l}\text { Subcellular } \\
\text { location }\end{array}$ & Function & Refs. \\
\hline \multicolumn{5}{|c|}{ TSC-specific markers } \\
\hline CD34 & CD34 & Cell surface & Cell adhesion and migration & [32] \\
\hline CD44 & $\mathrm{CD} 44$ & Cell surface & $\begin{array}{l}\text { Cell adhesion, migration and } \\
\text { metastasis }\end{array}$ & [33] \\
\hline DCAMKL1 & $\begin{array}{l}\text { Doublecortin like } \\
\text { kinase } 1\end{array}$ & Cytoplasm & $\begin{array}{l}\text { Epithelial-mesenchymal transition, } \\
\text { cancer invasion and metastasis }\end{array}$ & [34] \\
\hline ABCB5 & $\begin{array}{l}\text { ATP-binding cassette } \\
\text { subfamily B } \\
\text { member } 5\end{array}$ & Cell surface & Drug resistance & [35] \\
\hline MRPs & $\begin{array}{l}\text { Multidrug resistance } \\
\text { pumps }\end{array}$ & Cell surface & Drug resistance & {$[36]$} \\
\hline TIM3 & $\begin{array}{l}\mathrm{T} \text { cell immunoglobulin } \\
\text { and mucin domain } 3\end{array}$ & Cell surface & $\begin{array}{l}\text { Drug resistance, tumorigenesis, } \\
\text { self-renewal in leukemic stem } \\
\text { cells }\end{array}$ & {$[37]$} \\
\hline LgR5 & $\begin{array}{l}\text { Leucine-rich repeat- } \\
\text { containing G-protein- } \\
\text { coupled receptor } 5\end{array}$ & Cell surface & $\begin{array}{l}\text { WNT signaling and related cancer } \\
\text { metastasis }\end{array}$ & [38] \\
\hline Musashi-1 & $\begin{array}{l}\text { RNA-binding protein } \\
\text { Musashi homolog } 1\end{array}$ & $\begin{array}{l}\text { Nucleus and } \\
\text { cytoplasm }\end{array}$ & $\begin{array}{l}\text { Posttranscriptional regulation of } \\
\text { self-renewal and differentiation }\end{array}$ & [39] \\
\hline Brcal & Breast cancer 1 & Nucleus & $\begin{array}{l}\text { DNA repair of double-strand breaks } \\
\text { and mismatch }\end{array}$ & {$[40]$} \\
\hline HDACs & Histone deacetylases & Nucleus & $\begin{array}{l}\text { Histone modification, drug } \\
\text { resistance, cell proliferation, and } \\
\text { growth }\end{array}$ & {$[41,42]$} \\
\hline CD96 & Tactile & Cell surface & $\begin{array}{l}\text { Cell adhesive interaction and } \\
\text { specific TSCs marker }\end{array}$ & {$[43]$} \\
\hline PSCA & $\begin{array}{l}\text { Prostate stem cell } \\
\text { antigen }\end{array}$ & Cell surface & TSC-specific marker & {$[44]$} \\
\hline \multicolumn{5}{|c|}{ Overlapping markers } \\
\hline $\mathrm{CD} 9$ & CD9 antigen & Cell surface & $\begin{array}{l}\text { Cell adhesion, migration, and } \\
\text { regulation of cell development }\end{array}$ & [45] \\
\hline CD90 & $\begin{array}{l}\text { Thy- } 1 \text { cell surface } \\
\text { antigen }\end{array}$ & Cell surface & $\begin{array}{l}\text { Cell adhesion, migration, and } \\
\text { metastasis }\end{array}$ & [46] \\
\hline Integrin $\alpha 6$ & Integrin alpha 6 & Cell surface & $\begin{array}{l}\text { Cell adhesion, differentiation, } \\
\text { polarity, proliferation, survival/ } \\
\text { apoptosis }\end{array}$ & {$[47]$} \\
\hline $\begin{array}{l}\text { SSEA4 } \\
\text { SSEA1 }\end{array}$ & $\begin{array}{l}\text { Stage-specific } \\
\text { embryonic antigen } \\
4 \& 1\end{array}$ & Cell surface & Cell adhesion and migration & {$[33,48]$} \\
\hline Klf4 & Kruppel-like factor 1 & $\begin{array}{l}\text { Nucleus and } \\
\text { cytoplasm }\end{array}$ & $\begin{array}{l}\text { Tumor migration, invasion, and } \\
\text { ESCs self-renewal }\end{array}$ & [49] \\
\hline ЕрСАM & $\begin{array}{l}\text { Epithelial cell adhesion } \\
\text { molecule }\end{array}$ & Cell surface & Cell adhesion, and WNT signaling & {$[50]$} \\
\hline FriR & Frizzled receptors & Cell surface & $\begin{array}{l}\text { WNT signaling receptors, related to } \\
\text { cell proliferation, migration, and } \\
\text { survival. }\end{array}$ & [51] \\
\hline TDGF1/Cripto & $\begin{array}{l}\text { Teratocarcinoma- } \\
\text { derived growth } \\
\text { factor } 1\end{array}$ & $\begin{array}{l}\text { Cell surface and } \\
\text { cytoplasm }\end{array}$ & $\begin{array}{l}\text { Tumor anchorage-independent } \\
\text { growth and proliferation }\end{array}$ & {$[52]$} \\
\hline CD59 & CD59 & Cell surface & $\begin{array}{l}\text { Cell survival and inhibit } \\
\text { homologous complement- } \\
\text { mediated cytolysis }\end{array}$ & [53] \\
\hline ALDH1 & $\begin{array}{l}\text { Aldehyde } \\
\text { dehydrogenase } 1\end{array}$ & Cytoplasm & $\begin{array}{l}\text { Retinoid metabolism and self- } \\
\text { renewal, cell proliferation, drug } \\
\text { resistance }\end{array}$ & 54] \\
\hline $\mathrm{SCF}$ & Stem cell factor & Cytoplasm & $\begin{array}{l}\text { Drug resistance, cell migration and } \\
\text { stemness }\end{array}$ & {$[55,56]$} \\
\hline SCFR & $\begin{array}{l}\text { Mast/stem cell growth } \\
\text { factor receptor, } \\
\text { CD117 }\end{array}$ & Cell surface & $\begin{array}{l}\text { Drug resistance, cell migration and } \\
\text { stemness }\end{array}$ & {$[55,56]$} \\
\hline
\end{tabular}


TABle 1. (CONTINUED)

\begin{tabular}{|c|c|c|c|c|}
\hline Abbreviation & Full name & $\begin{array}{l}\text { Subcellular } \\
\text { location }\end{array}$ & Function & Refs. \\
\hline NAC1 & $\begin{array}{l}\text { Nucleus accumbens- } \\
\text { associated protein1 }\end{array}$ & Nucleus & $\begin{array}{l}\text { Drug resistance and ESCs } \\
\text { self-renewal }\end{array}$ & [57] \\
\hline CD133 & CD133 & $\begin{array}{l}\text { Cell surface and } \\
\text { cytoplasm }\end{array}$ & $\begin{array}{l}\text { Cell proliferation and } \\
\text { dedifferentiation }\end{array}$ & {$[58]$} \\
\hline DPPA2/4 & $\begin{array}{l}\text { Developmental } \\
\text { pluripotency- } \\
\text { associated 2/4 }\end{array}$ & Nucleus & $\begin{array}{l}\text { Tumor cell initiation, proliferation } \\
\text { and ESCs maintenance } \\
\text { of pluripotency }\end{array}$ & {$[59]$} \\
\hline Sall4 & $\begin{array}{l}\text { Spalt-like transcription } \\
\text { factor } 4\end{array}$ & Nucleus & $\begin{array}{l}\text { Cell proliferation, drug resistance, } \\
\text { and ESCs self-renewal }\end{array}$ & {$[60]$} \\
\hline Zfx & $\begin{array}{l}\text { Zinc finger protein } \\
\text { X-linked }\end{array}$ & Nucleus & Cell proliferation & {$[61]$} \\
\hline STAT3 & $\begin{array}{l}\text { Signal transducer and } \\
\text { activator of } \\
\text { transcription } 3\end{array}$ & $\begin{array}{l}\text { Cytoplasm and } \\
\text { nucleus }\end{array}$ & $\begin{array}{l}\text { Tumor cell proliferation, survival, } \\
\text { invasion, and ESCs self-renewal }\end{array}$ & {$[62]$} \\
\hline SSEA3 & $\begin{array}{l}\text { Stage-specific } \\
\quad \text { embryonic antigen } 3\end{array}$ & Cell surface & $\begin{array}{l}\text { Cell survival and cell proliferation } \\
\text { but not necessary for } \\
\text { maintenance of pluripotent status }\end{array}$ & {$[63]$} \\
\hline Nanog & Homebox protein nanog & Nucleus & $\begin{array}{l}\text { Self-renewal, maintenance of } \\
\text { pluripotency, and drug resistance }\end{array}$ & {$[64]$} \\
\hline HMGA2 & $\begin{array}{l}\text { High-mobility group } \\
\text { AT-hook } 2\end{array}$ & Nucleus & Self-renewal and differentiation & {$[65]$} \\
\hline GJA & Gap junction protein & Cell surface & $\begin{array}{l}\text { Self-renewal and intercellular } \\
\text { communication }\end{array}$ & {$[66]$} \\
\hline Oct-3/-4 & $\begin{array}{l}\text { Octamer-binding } \\
\text { transcription } \\
\text { factor } 3 / 4\end{array}$ & Nucleus & $\begin{array}{l}\text { Dedifferentiation and ESCs } \\
\text { self-renewal }\end{array}$ & [67] \\
\hline Sox 2 & $\begin{array}{l}\text { (Sex-determining } \\
\text { region Y)-box } 2\end{array}$ & Nucleus & $\begin{array}{l}\text { Tumor initiation and ESCs } \\
\text { self-renewal }\end{array}$ & {$[68]$} \\
\hline \multicolumn{5}{|c|}{ ESC-specific markers } \\
\hline E-Cadherin & E-Cadherin & Cell surface & $\begin{array}{l}\text { Cell adhesion, migration, } \\
\text { and pluripotency }\end{array}$ & [69] \\
\hline Tbn & Taube nuss & Nucleus & $\begin{array}{l}\text { Cell survival, regulating the extent } \\
\text { of programmed cell death }\end{array}$ & {$[70]$} \\
\hline ECAT1 & $\begin{array}{l}\text { ES cell associated } \\
\text { transcript } 1\end{array}$ & Nucleus & $\begin{array}{l}\text { Oocyte maturation and } \\
\text { preimplantation development }\end{array}$ & {$[71]$} \\
\hline GCNF & $\begin{array}{l}\text { Germ cell nuclear } \\
\text { factor }\end{array}$ & Nucleus & Differentiation & {$[72]$} \\
\hline UTF1 & $\begin{array}{l}\text { Undifferentiated } \\
\text { embryonic cell } \\
\text { transcription factor } 1\end{array}$ & Nucleus & $\begin{array}{l}\text { ESCs self-renewal and } \\
\text { differentiation }\end{array}$ & {$[73]$} \\
\hline ECAT11 & $\begin{array}{l}\text { ES cell-associated } \\
\text { transcript } 11\end{array}$ & Nucleus & ESCs self-renewal & [74] \\
\hline FoxD3 & $\begin{array}{l}\text { Forkhead box protein } \\
\text { D3 }\end{array}$ & Nucleus & ESCs self-renewal & [75] \\
\hline Fbx 15 & F-box-only protein & Nucleus & ESCs self-renewal & [76] \\
\hline DPPA3/5 & $\begin{array}{l}\text { Developmental } \\
\text { pluripotency- } \\
\text { associated 3/5 }\end{array}$ & Nucleus & $\begin{array}{l}\text { Acquisition and maintenance } \\
\text { of pluripotency }\end{array}$ & [77-79] \\
\hline $\operatorname{Rex} 1$ & Reduced expression 1 & Nucleus & $\begin{array}{l}\text { Acquisition and maintenance } \\
\text { of pluripotency }\end{array}$ & {$[80]$} \\
\hline TRA-1-60/80 & $\begin{array}{l}\text { Podocalyxin-like } \\
\text { protein } 1\end{array}$ & Cell surface & ESC-specific marker & {$[81]$} \\
\hline
\end{tabular}

tumor cell survival (eg, invasion and metastasis), Conversely, cells composing normal stem cell niches (eg, neural stem cell niches) affect stem cell differentiation in addition to preserving their self-renewal through numerous biophysical and biochemical mechanisms [87]. Presentation of systematical comparisons between CSC niches and those of regular stem cells is beyond the scope of the current work; however, such analytical outcomes will undoubtedly help us to better understand the fundamental biology of CSCs. The data have kept kindling our intention to suggest that the fundamental developmental biology principles should caution application of the stem cell concept in labeling any terminal oncological and pathological cell phenomena [83]. 


\section{Present Definitions of CSCs}

To substantiate our proposal of defining an alternative term for CSCs, we have analyzed the following definitions currently used to describe CSCs [88].

1. CSCs may directly derive from normal stem cells through genetic mutation. Thus, these cells have the ability for self-renewal and differentiation into all heterogeneous tumor cell phenotypes of a particular cancer (note: intratumoral heterogeneity maximizes cancer cell survival through constant adaptation without real possibility to form any sustainable system that can be stemmed for).

2. CSCs may directly derive from normal progenitor cells that may acquire tumor "stemness-like" biology through further accumulation of genetic abnormalities, including mutations and/or abnormal epigenetic modifications.

3. CSCs may directly derive from normal growing or static adult cells through genetic mutations and other mechanisms to trigger dedifferentiation. For example, by expression of hTERT, H-RasV12, and SV40LT and ST, human skin fibroblasts can be reprogrammed to have properties of CSCs [89].

4. Mathematical modeling and data analyses of thermal conditioning of glioblastoma cells suggested that stem cell-like tumor initiation cells, regardless of origin, may not be a fixed population of neoplastic cells [30]. Instead, CSC capacities such as expressions of representative markers, metastasis, oncolytic drug resistance and symmetric or asymmetric cell division may likely be a cluster of transient events occurring in a subpopulation of cancer cells when stressed or induced by environmental, epigenetic, genetic, and therapeutic impacts. Thus, the actual number of CSCs existing in a given tumor for a particular time point is determined by the optimal probability of the unilateral survival and growth of the entire tumor [90,91].

5. CSCs can emerge under varied combinatorial regimens that comprise all the aforementioned scenarios, which is a rational extrapolation that we made.

With the introduction of the fourth and fifth definitions of CSCs, data previously used as evidence to question real existence of CSCs can now be turned into valuable information to suggest an alternative concept. As an example, CSC composition ratio in different tumors might range from $0.2 \%$ to $82.5 \%$. Using standardized limiting dilution assays, researchers uncovered that this ratio actually increased in breast cancers along their Stage I to Stage III progression. In contrast to Stage III-IV melanomas, tumorigenic cell ratios remained steadily at around 30\% [92]. It has been known that CSCs in the same tumor could carry overlapping, nonoverlapping, or even varied characteristic markers [93,94].

\section{CSCs Are Tumor Survival Cells}

In addition to the aforedescribed results, reports showed that the specific molecular mechanisms underlying commonly targeted tumor cell "stemness" are unstable. The observations of genetic instability imply a real possibility that different new parental CSC lines may continuously be produced in high-grade malignant tumors. This explains why expressions of some CSC markers are time dependent
[95]. With regard to the latter point, an informative comparison case can be made by examining key profiles of ESCs versus those of ECCs that have been traditionally portrayed as opposite sides of the same coin [95].

ECCs have been identified as the "stem cells of teratocarcinomas" and as the malignant counterparts of ESCs for mammals. Unlike ESCs that are derived from the inner cell mass of early blastocyst-stage embryos, ECCs are isolated from embryonal teratocarcinomas. It is only after prolonged in vitro culture under certain regimens that some human ESCs (hESCs) start acquiring karyotypic modifications that can be observed in human ECCs (hECCs). Over the chronic incubation process, hESCs can manifest faster proliferation rate and become more maintainable in vitro. Markedly, the more transformed hESCs can form teratocarcinoma-like neoplasms in SCID mice following transplantation. Conversely, the donor hESCderived teratocarcinoma was able to give rise to characterizable hESCs in vitro. It was therefore concluded that hESCs under particular in vitro induction conditions could develop in similar ways that hECCs do during tumorigenesis [96].

Our analysis, based on a crossdisciplinary approach of stem cell biology and developmental neurobiology, suggests that the in vitro transforming process may actually be a journey for ESCs to gradually lose their repertoire of authentic stemness biology, for which ECCs either do not own or are in severe deficiency. This postulation renders the two types of cells not at all belonging to "opposite sides of the same coin" (ie, both ESCs and ECCs possess stemness biology). The conclusion is corroborated by findings from more advanced investigations. In a study of the hECC lines, NT2/D1 and NT2/B9, which were clonally derived from a xenograft tumor of the teratocarcinoma cell line Tera-2, extensive differentiation could be induced in vitro by retinoic acid treatment [97]. This differentiation was particularly marked by the disappearance of SSEA-3 that is typically expressed by hECCs. Among the differentiated cell phenotypes, hECC-produced neuron-like cells showed morphological features of neurites and expressed tetanus toxin receptors and neurofilament proteins [97]. But these NT2/N neurons did not further mature into true neurons that could express phosphorylated neurofilament heavy (NF-H) proteins after engraftment in young adult or developmental rodent brains [98]. They nevertheless survived for $>12$ weeks to $>1$ year in rat brains under immunosuppression $[98,99]$ and for more than 27 months in a poststroke human brain [99].

The fact that NT2/N cells showed much longer graft survival duration in the brain relative to that of freshly isolated primary neurons or neural progenitor cells indicates that they might have obtained additionally augmented individual survival efficacy, albeit reduction of neural stemness (ie, diminished ability to differentiate into mature neurons) [98-101]. Accordingly, the NT2/N neurons, not the predifferentiated NT2 progenitor cells, constitutively synthesized intracellular beta/A4 peptide, a major pathologic peptide accumulating in Alzheimer disease (AD) brains, and released it into the cell culture medium [102]. The secreted form (sAPP) of the AD amyloid beta/A4 protein precursor (APP) is a potent player in promoting neurite extension, synaptic formation, overall neurotropic support, and antiexcitotoxicity effect for neuronal cells, as well as in enhancing fibroblast growth [103-108]. Clearly, the gain of function in the 
ECC and ECC-derived neuron-like cells is the selfsurvival capability (eg, production of sAPP, enhanced grafting, etc.). Contrariwise, the loss of function for ECC and ECC-differentiated neuron-like cells is the diminished capacity of authentic stemness (eg, their inability to become mature neurons, defect in functional integration, etc.). Following this novel route of logical reasoning, cautions are deemed necessary when trying to use the NT2/N cells in vitro for investigating NSC and adult neuronal properties, modeling neuronal diseases, or discovering neuronal therapeutics $[109,110]$. We believe that data extrapolation without factoring the essential cell biology discrepancy could yield misleading information because changes in survival metabolic events may induce alterations of stemness marker presentations. For example, expression of CD9 gene and protein, a cell transmembrane molecule family mediating signal transductions, showed selective upregulation in human glioblastoma stem cell-like cells. CD9 silencing in three CD133+ glioblastoma cell lines triggered amelioration of cancer cell proliferation, survival, invasion, and self-renewal ability through impacting activation patterns of the Akt, MapK, and Stat3 signaling transducers, in which the signaling pathways are mainly involved in cell survival functions, which in turn resulted in expression alternations of CD133, nestin, and SOX2 [45].

Collectively, the metabolic, mitotic, and survival behavioral features as well as the overall life journey endpoints of the currently termed CSCs are vitally different from those of conventionally defined stem cells. Due to the permeating influence of stemness as an established concept that has been academically inscribed for characterizing normal primordial or tissue-specific germ cells, the use of CSC as a nomenclature may cast shadow over conscious and subconscious reasoning of investigators when they aim to tackle malignant essentials of tumor cells. Moreover, the concept of CSC certainly does not hold the original metaphorical implication of stem cells for their capacity to give rise to homeostatic and reproducible multicellular organisms, including human bodies. Therefore, establishing a new nomenclature of tumor survival cell (TSC) to replace CSC appears to be highly valuable since unilateral tumor cell survival essentials consist of endeavors of self-renewal, proliferation, limited differentiation to generate adaptive heterogeneity, migration, metastasis, immune diversity, and drug resistance.

\section{Potential Benefits of Adopting TSC as a New Nomenclature to Replace or Coexist with CSC}

Application of TSC as an academically and scientifically further justified nomenclature may benefit the intellectual and research fields for its clarity and uniqueness that are tangibilized by the following perspectives.

1. To add special insight to the word "stem" when it is used to describe cancer cells for research and therapeutic development [110].

2. To dissect the definitive difference between TSCs and normal stem cells.

TSCs have pathologically maximized levels of individual and group survival ability and utterly perished capacity for authentic stemness biology. TSCs behave like desperados, tumor cell outlaws that act desperately to survive and appear unstoppable, but they are eventually wiped out in their selfrendered catastrophic circumstances. By contrast, ESCs or tissue-specific progenitor cells maintain a homeostatic equilibrium between its stemness biology and individual survival drive to build a sustainable and reproducible entity.

3. To reveal the lack of real stemness capability in CSCs. This will help to refocus on unilateral cell survival mechanisms when devising therapies to block cancer metastasis [111]. As a testable hypothesis, what is truly needed for curing the so called CSCs may likely be resurrection of authentic stemness biology and mitigation of the abnormally augmented survival biology inside tumor cells.

4. To emphasize the endpoint of the essential functions of the TSCs that is to carry out desperado-like survival behaviors (DSB). DSB as a novel term of cancer cell oncology describes the state or process of being able to live by all means available, mostly in spite of unfavorable accidents and tribulations, actually in a self-triggered perturbing, stressful, and unsustainable environment. Manifestly, tumor cell DSB do not lead to any real continuity of individual tumor cells or tumor mass as an entity. Through a single spearheaded DSB-driven relentless proliferation, growth, and metastasis, malignant tumor cells will eventually cause the imminent demise of their host organism, followed by reaching the termination of their own journey of survival. Hence, the actual use of the term TSC may further improve the fine-tuning of the direction of our reasoning in search of the oncological prerequisites of these cells in addition to providing the needed demarcation of principal differences between them and the classically entitled stem cells.

\section{Summary}

There have been increasingly convincing experimental and clinical data that validate the genetic, epigenetic, and phenotypic heterogeneity of cells comprising malignant tumors. Although questions remain with regard to the consistency and expression levels of specific markers in a subpopulation of cancer cells behaving like stem cell-like tumor initiation cells (ie, CSCs) as well as complexity of CSC oncology, they have not been able to shake the foundation of the concept of CSCs. The current CSC models illuminate tumor generation capabilities of subpopulations of self-renewable and tumor differentiable cells that drive cancer progression via producing oncologic heterogeneity, resistance to oncolytic assaults, and the ultimate death of tumor cells due to host decease. The uncertain oncological feature and conflicting genetic signature of the CSCs (eg, CSC markers mostly are genes in charge of survival, not stemness) suggest a necessity of inaugurating a new nomenclature for the demarcation of the fundamental difference between these cells and physiological stem cells to promote cancer and stem cell research.

What emerged from our analysis is a fine but definitive line between the authentic stemness biology and the newly defined cancer cell survivology. We hereby recommend introducing the term of TSCs (Tumor Survival Cells). Implementation of this proposal may facilitate future work to 
focus on investigating key events that have gone awry in TSCs to uncover differences between the three bodies of mechanisms underlying normal stem cell biology, cancer cells, and DSB of CSCs/TSCs, respectively (Fig. 1 and Table 1). Furthermore, by weighing the characteristics of limited "developmental hierarchy" in cancer cells and full-scale "functional multipotency" of normal stem cells, researchers may explore consequences of nongenetic variability, rare clones, and clonal dynamics within a particular tumor, as well as between the tumor clones and the host microenvironment. Such undertakings may determine the oncological essentials of TSCs in terms of their endpoint of survival, defects in authentic stemness biology, and the impacts on the host. The findings will reveal crucial targets (eg, stemness defect, stemness resurrection, unchecked survival drive, etc.) for assessing risk-based patient selection for receiving a particular medical procedure and developing efficacious targeted treatment for malignant tumors $[10,82,112,113]$.

\section{Acknowledgments}

This paper was generated from the accumulated reading notes of Y.D.T. alongside cross-disciplinary research collaborations with his colleagues and trainees. Research projects at Dr. Teng's Laboratories are funded by DoD, CASISNASA, and VA RRD, and by the Brain Science Foundation and the Gordon Project to Treat Clinical Paralysis (with Dr. Zafonte) at the HMS and SRHN. L.W. was additionally supported by fellowships provided by Wuhan Union Hospital and H.Z.U.S.T. (Sponsor: Y.D.T.). CSC-TSC phenotype targeting in Dr. Ulrich's laboratory is funded by a grant from the São Paulo Research Foundation (FAPESP project no. 2012/50880-4), Brazil.

\section{Author Disclosure Statement}

No competing financial interests exist.

\section{References}

1. Haeckel E, ed. (1868). Natürliche Schöpfungsgeschichte (Natural History of Creation), 15th Lecture. Georg Reimer, Berlin, DE.

2. Ramalho-Santos $M$ and $H$ Willenbring. (2007). On the origin of the term "stem cell". Cell Stem Cell 1:35-38.

3. Richards RJ, ed. (2008). The Tragic Sense of Life: Ernst Haeckel and the Struggle Over Evolutionary Thought. University of Chicago Press, Chicago, IL.

4. Johach E, ed. (2008). Krebszelle und Zellenstaat: Zur medizinischen und politischen Metaphorik in Rudolf Virchows Zellularpathologie (Cancer Cells and Cell State: To the Medical and Political Use of Metaphor in Rudolf Virchow's Cellular Pathology). Rombach Verlag Kg, Freiburg im Breisgau, DE.

5. Cohnheim J, ed. (1877-1880). Vorlesungen über allgemeine Pathologie: Ein Handbuch für Ärzte und Studierende (Lectures on general Pathology: A handbook for physicians and students). Hirschwald, Berlin, DE.

6. Witschi E. (1948). Migration of the germ cells of human embryos from the yolk sac to the primitive gonadal folds. Contrib Embryol 32:67-80.

7. Kleinsmith LJ and GB Pierce, Jr. (1964). Multipotentiality of single embryonal carcinoma cells. Cancer Res 24: 1544-1551.
8. Evans MJ and MH Kaufman. (1981). Establishment in culture of pluripotential cells from mouse embryos. Nature 292:154-156.

9. Martin GR. (1981). Isolation of a pluripotent cell line from early mouse embryos cultured in medium conditioned by teratocarcinoma stem cells. Proc Natl Acad Sci U S A 78:7634-7638.

10. Teng YD, FN Santos, PM Black, D Konya, KI Park and RL Sidman. (2008). Neural stem cells: multipotency beyond self-renewal and phenotypic differentiation. In: Principles of Regenerative Medicine Atala A, R Lanza, Thomson, RM Nerem, eds. Elsevier, San Diego, CA, pp 300-317.

11. Shamblott MJ, J Axelman, S Wang, EM Bugg, JW Littlefield, PJ Donovan, PD Blumenthal, GR Huggins and JD Gearhart. (1998). Derivation of pluripotent stem cells from cultured human primordial germ cells. Proc Natl Acad Sci U S A 95:13726-13731.

12. Thomson JA, J Itskovitz-Eldor, SS Shapiro, MA Waknitz, JJ Swiergiel, VS Marshall and JM Jones. (1998). Embryonic stem cell lines derived from human blastocysts. Science 282:1145-1147.

13. Bruce WR and H Van Der Gaag. (1963). A quantitative assay for the number of murine lymphoma cells capable of proliferation in vivo. Nature 199:79-80.

14. Till JE and EA McCulloch. (1961). A direct measurement of the radiation sensitivity of normal mouse bone marrow cells. Radiat Res 14:213-222.

15. Nowell PC. (1976). The clonal evolution of tumor cell populations. Science 194:23-28.

16. Fearon ER and B Vogelstein. (1990). A genetic model for colorectal tumorigenesis. Cell 61:759-767.

17. Eirew P, A Steif, J Khattra, G Ha, D Yap, H Farahani, K Gelmon, S Chia, C Mar, et al. (2015). Dynamics of genomic clones in breast cancer patient xenografts at singlecell resolution. Nature 518:422-426.

18. Lapidot T, C Sirard, J Vormoor, B Murdoch, T Hoang, J Caceres-Cortes, M Minden, B Paterson, MA Caligiuri and JE Dick. (1994). A cell initiating human acute myeloid leukaemia after transplantation into SCID mice. Nature 367:645-648.

19. Reya T, SJ Morrison, MF Clarke and IL Weissman. (2001). Stem cells, cancer, and cancer stem cells. Nature 414:105-111.

20. Al-Hajj M, MS Wicha, A Benito-Hernandez, SJ Morrison and MF Clarke. (2003). Prospective identification of tumorigenic breast cancer cells. Proc Natl Acad Sci U S A 100:3983-3988.

21. Shipitsin M and K Polyak. (2008). The cancer stem cell hypothesis: in search of definitions, markers, and relevance. Lab Invest 88:459-463.

22. Shah A, S Patel, J Pathak, N Swain and S Kumar. (2014). The evolving concepts of cancer stem cells in head and neck squamous cell carcinoma. Sci World J 2014:842491.

23. Clevers H. (2011). The cancer stem cell: premises, promises and challenges. Nat Med 17:313-319.

24. Ye X, WL Tam, T Shibue, Y Kaygusuz, F Reinhardt, E $\mathrm{Ng}$ Eaton and RA Weinberg. (2015). Distinct EMT programs control normal mammary stem cells and tumourinitiating cells. Nature 525:256-260.

25. Stefania D and D Vergara. (2017). The many-faced program of epithelial-mesenchymal transition: a system biology-based view. Front Oncol 7:274.

26. Malta TM, A Sokolov, AJ Gentles, T Burzykowski, L Poisson, JN Weinstein, B Kamińska, J Huelsken, L 
Omberg, et al. (2018). Machine learning identifies stemness features associated with oncogenic dedifferentiation. Cell 173:338-354.e15.

27. Bensellam M, JC Jonas and DR Laybutt. (2018). Mechanisms of beta-cell dedifferentiation in diabetes: recent findings and future research directions. J Endocrinol 236: R109-R143.

28. Chosa N and A Ishisaki. (2018). Two novel mechanisms for maintenance of stemness in mesenchymal stem cells: SCRG1/BST1 axis and cell-cell adhesion through $\mathrm{N}$ cadherin. Jpn Dent Sci Rev 54:37-44.

29. Molina ES, MM Pillat, V Moura-Neto, TT Lah and H Ulrich. (2014). Glioblastoma stem-like cells: approaches for isolation and characterization. J Cancer Stem Cell Res $1: \mathrm{e} 1007$.

30. Zeng X, I Han, M Abd-El-Barr, Z Aljuboori, JE Anderson, JH Chi, RD Zafonte and YD Teng. (2016). The effects of thermal preconditioning on oncogenic and intraspinal cord growth features of human glioma cells. Cell Transplant 25:2099-2109.

31. Chen X, R Liao, D Li and J Sun. (2017). Induced cancer stem cells generated by radiochemotherapy and their therapeutic implications. Oncotarget 8:17301-17312.

32. Cho SY, M Xu, J Roboz, M Lu, J Mascarenhas and $\mathrm{R}$ Hoffman. (2010). The effect of CXCL12 processing on CD34+ cell migration in myeloproliferative neoplasms. Cancer Res 70:3402-3410.

33. Noto Z, T Yoshida, M Okabe, C Koike, M Fathy, H Tsuno, K Tomihara, N Arai, M Noguchi and T Nikaido. (2013). CD44 and SSEA-4 positive cells in an oral cancer cell line HSC-4 possess cancer stem-like cell characteristics. Oral Oncol 49:787-795.

34. Sureban SM, R May, SA Lightfoot, AB Hoskins, M Lerner, DJ Brackett, RG Postier, R Ramanujam, A Mohammed, et al. (2011). DCAMKL-1 regulates epithelial-mesenchymal transition in human pancreatic cells through a miR-200adependent mechanism. Cancer Res 71:2328-2338.

35. Frank NY, A Margaryan, Y Huang, T Schatton, AM Waaga-Gasser, M Gasser, MH Sayegh, W Sadee and MH Frank. (2005). ABCB5-mediated doxorubicin transport and chemoresistance in human malignant melanoma. Cancer Res 65:4320-4333.

36. Kondo T, T Setoguchi and T Taga. (2004). Persistence of a small subpopulation of cancer stem-like cells in the C6 glioma cell line. Proc Natl Acad Sci U S A 101:781-786.

37. Jan M, MP Chao, AC Cha, AA Alizadeh, AJ Gentles, IL Weissman and R Majeti. (2011). Prospective separation of normal and leukemic stem cells based on differential expression of TIM3, a human acute myeloid leukemia stem cell marker. Proc Natl Acad Sci U S A 108:5009-5014.

38. de Sousa e Melo F, AV Kurtova, JM Harnoss, N Kljavin, JD Hoeck, J Hung, JE Anderson, EE Storm, Z Modrusan, et al. (2017). A distinct role for Lgr5(+) stem cells in primary and metastatic colon cancer. Nature 543:676-680.

39. Kuang RG, Y Kuang, QF Luo, CJ Zhou, R Ji and JW Wang. (2013). Expression and significance of Musashi-1 in gastric cancer and precancerous lesions. World J Gastroenterol 19:6637-6644.

40. Bai F, HL Chan, A Scott, MD Smith, C Fan, JI Herschkowitz, CM Perou, AS Livingstone, DJ Robbins, AJ Capobianco and XH Pei. (2014). BRCA1 suppresses epithelial-to-mesenchymal transition and stem cell dedifferentiation during mammary and tumor development. Cancer Res 74:6161-6172.
41. Song KH, CH Choi, HJ Lee, SJ Oh, SR Woo, SO Hong, KH Noh, H Cho, EJ Chung, et al. (2017). HDAC1 upregulation by NANOG promotes multidrug resistance and a stem-like phenotype in immune edited tumor cells. Cancer Res 77:5039-5053.

42. Witt AE, CW Lee, TI Lee, DJ Azzam, B Wang, C Caslini, F Petrocca, J Grosso, M Jones, et al. (2017). Identification of a cancer stem cell-specific function for the histone deacetylases, HDAC1 and HDAC7, in breast and ovarian cancer. Oncogene 36:1707-1720.

43. Hosen N, CY Park, N Tatsumi, Y Oji, H Sugiyama, M Gramatzki, AM Krensky and IL Weissman. (2007). CD96 is a leukemic stem cell-specific marker in human acute myeloid leukemia. Proc Natl Acad Sci U S A 104:11008-11013.

44. Guzmán-Ramírez N, M Völler, A Wetterwald, M Germann, NA Cross, CA Rentsch, J Schalken, GN Thalmann and MG Cecchini. (2009). In vitro propagation and characterization of neoplastic stem/progenitor-like cells from human prostate cancer tissue. Prostate 69:1683-1693.

45. Podergajs N, H Motaln, U Rajčević, U Verbovšek, M Koršič, N Obad, H Espedal, M Vittori, C Herold-Mende, et al. (2016). Transmembrane protein CD9 is glioblastoma biomarker, relevant for maintenance of glioblastoma stem cells. Oncotarget 7:593-609.

46. Zhang K, S Che, Z Su, S Zheng, H Zhang, S Yang, W Li and J Liu. (2018). CD90 promotes cell migration, viability and sphereforming ability of hepatocellular carcinoma cells. Int J Mol Med 41:946-954.

47. Gómez-Miragaya J, M Palafox, L Paré, G Yoldi, I Ferrer, S Vila, P Galván, P Pellegrini, H Pérez-Montoyo, et al. (2017). Resistance to taxanes in triple-negative breast cancer associates with the dynamics of a CD49f+ tumorinitiating population. Stem Cell Rep 8:1392-1407.

48. Son MJ, K Woolard, DH Nam, J Lee and HA Fine. (2009). SSEA-1 is an enrichment marker for tumor-initiating cells in human glioblastoma. Cell Stem Cell 4:440-452.

49. Yu F, J Li, H Chen, J Fu, S Ray, S Huang, H Zheng and W Ai. (2011). Kruppel-like factor 4 (KLF4) is required for maintenance of breast cancer stem cells and for cell migration and invasion. Oncogene 30:2161-2172.

50. Maetzel D, S Denzel, B Mack, M Canis, P Went, M Benk, C Kieu, P Papior, PA Baeuerle, M Munz and O Gires. (2009). Nuclear signalling by tumour-associated antigen EpCAM. Nat Cell Biol 11:162-171.

51. Cantilena S, F Pastorino, A Pezzolo, O Chayka, V Pistoia, M Ponzoni and A Sala. (2011). Frizzled receptor 6 marks rare, highly tumourigenic stem-like cells in mouse and human neuroblastomas. Oncotarget 2:976-983.

52. Francescangeli F, P Contavalli, ML De Angelis, M Baiocchi, G Gambara, A Pagliuca, A Fiorenzano, C Prezioso, A Boe, et al. (2015). Dynamic regulation of the cancer stem cell compartment by Cripto-1 in colorectal cancer. Cell Death Differ 22:1700-1713.

53. Chen J, P Ding, L Li, H Gu, X Zhang, L Zhang, N Wang, L Gan, Q Wang, W Zhang and W Hu. (2017). CD59 regulation by SOX2 is required for epithelial cancer stem cells to evade complement surveillance. Stem Cell Rep 8: 140-151.

54. Jiang F, Q Qiu, A Khanna, NW Todd, J Deepak, L Xing, H Wang, Z Liu, Y Su, SA Stass and RL Katz. (2009). Aldehyde dehydrogenase 1 is a tumor stem cell-associated marker in lung cancer. Mol Cancer Res 7:330-338.

55. Siemens H, R Jackstadt, M Kaller and H Hermeking. (2013). Repression of c-Kit by p53 is mediated by miR-34 
and is associated with reduced chemoresistance, migration and stemness. Oncotarget 4:1399-1415.

56. Krivtsov AV, D Twomey, Z Feng, MC Stubbs, Y Wang, J Faber, JE Levine, J Wang, WC Hahn, et al. (2006). Transformation from committed progenitor to leukaemia stem cell initiated by MLL-AF9. Nature 442:818-822.

57. Yap KL, SI Fraley, MM Thiaville, N Jinawath, K Nakayama, J Wang, TL Wang, D Wirtz and IeM Shih. (2012). NAC1 is an actin-binding protein that is essential for effective cytokinesis in cancer cells. Cancer Res 72:4085-4096.

58. Angelastro JM and MW Lamé. (2010). Overexpression of CD133 promotes drug resistance in C6 glioma cells. Mol Cancer Res 8:1105-1115.

59. Tung PY, NV Varlakhanova and PS Knoepfler. (2013). Identification of DPPA4 and DPPA2 as a novel family of pluripotency-related oncogenes. Stem Cells 31:2330-2342.

60. Oikawa T, A Kamiya, M Zeniya, H Chikada, AD Hyuck, Y Yamazaki, E Wauthier, H Tajiri, LD Miller, et al. (2013). Sal-like protein 4 (SALL4), a stem cell biomarker in liver cancers. Hepatology 57:1469-1483.

61. Wang C, SY Fu, MD Wang, WB Yu, QS Cui, HR Wang, H Huang, W Dong, WW Zhang, et al. (2017). Zinc finger protein X-linked promotes expansion of $\operatorname{EpCAM}(+)$ cancer stem-like cells in hepatocellular carcinoma. Mol Oncol 11:455-469.

62. Zhou J, J Wulfkuhle, H Zhang, P Gu, Y Yang, J Deng, JB Margolick, LA Liotta, E Petricoin, 3rd and Y Zhang. (2007). Activation of the PTEN/mTOR/STAT3 pathway in breast cancer stem-like cells is required for viability and maintenance. Proc Natl Acad Sci U S A 104:16158-16163.

63. Chiou SH, ML Wang, YT Chou, CJ Chen, CF Hong, WJ Hsieh, HT Chang, YS Chen, TW Lin, HS Hsu and CW Wu. (2010). Coexpression of Oct4 and Nanog enhances malignancy in lung adenocarcinoma by inducing cancer stem cell-like properties and epithelial-mesenchymal transdifferentiation. Cancer Res 70:10433-10444.

64. Cheung SK, PK Chuang, HW Huang, WW HwangVerslues, CH Cho, WB Yang, CN Shen, M Hsiao, TL Hsu, CF Chang and CH Wong. (2016). Stage-specific embryonic antigen-3 (SSEA-3) and beta3GalT5 are cancer specific and significant markers for breast cancer stem cells. Proc Natl Acad Sci U S A 113:960-965.

65. Yu H, HH Lim, NO Tjokro, P Sathiyanathan, S Natarajan, TW Chew, T Klonisch, SD Goodman, U Surana and P Dröge. (2014). Chaperoning HMGA2 protein protects stalled replication forks in stem and cancer cells. Cell Rep 6:684-697.

66. Hitomi M, LP Deleyrolle, EE Mulkearns-Hubert, A Jarrar, M Li, M Sinyuk, B Otvos, S Brunet, WA Flavahan, et al. (2015). Differential connexin function enhances selfrenewal in glioblastoma. Cell Rep 11:1031-1042.

67. Kumar SM, S Liu, H Lu, H Zhang, PJ Zhang, PA Gimotty, M Guerra, W Guo and X Xu. (2012). Acquired cancer stem cell phenotypes through Oct4-mediated dedifferentiation. Oncogene 31:4898-4911.

68. Boumahdi S, G Driessens, G Lapouge, S Rorive, D Nassar, M Le Mercier, B Delatte, A Caauwe, S Lenglez, et al. (2014). SOX 2 controls tumour initiation and cancer stem-cell functions in squamous-cell carcinoma. Nature 511:246-250.

69. Redmer T, S Diecke, T Grigoryan, A Quiroga-Negreira, W Birchmeier and D Besser. (2011). E-cadherin is crucial for embryonic stem cell pluripotency and can replace OCT4 during somatic cell reprogramming. EMBO Rep 12:720-726.
70. Voss AK, T Thomas, P Petrou, K Anastassiadis, H Schöler and P Gruss. (2000). Taube nuss is a novel gene essential for the survival of pluripotent cells of early mouse embryos. Development 127:5449-5461.

71. Liu C, M Li, T Li, H Zhao, J Huang, Y Wang, Q Gao, Y $\mathrm{Yu}$ and Q Shi. (2016). ECAT1 is essential for human oocyte maturation and pre-implantation development of the resulting embryos. Sci Rep 6:38192.

72. Akamatsu W, B DeVeale, H Okano, AJ Cooney and D van der Kooy. (2009). Suppression of Oct4 by germ cell nuclear factor restricts pluripotency and promotes neural stem cell development in the early neural lineage. J Neurosci 29:2113-2124.

73. van den Boom V, SM Kooistra, M Boesjes, B Geverts, AB Houtsmuller, K Monzen, I Komuro, J Essers, LJ DrenthDiephuis and BJ Eggen. (2007). UTF1 is a chromatinassociated protein involved in ES cell differentiation. J Cell Biol 178:913-924.

74. Närvä E, N Rahkonen, MR Emani, R Lund, JP Pursiheimo, J Nästi, R Autio, O Rasool, K Denessiouk, et al. (2012). RNA-binding protein L1TD1 interacts with LIN28 via RNA and is required for human embryonic stem cell self-renewal and cancer cell proliferation. Stem Cells 30:452-460.

75. Zhu L, S Zhang and Y Jin. (2014). Foxd3 suppresses NFAT-mediated differentiation to maintain self-renewal of embryonic stem cells. EMBO Rep 15:1286-1296.

76. Tokuzawa Y, E Kaiho, M Maruyama, K Takahashi, K Mitsui, M Maeda, H Niwa and S Yamanaka. (2003). Fbx15 is a novel target of Oct $3 / 4$ but is dispensable for embryonic stem cell self-renewal and mouse development. Mol Cell Biol 23:2699-2708.

77. Xu X, L Smorag, T Nakamura, T Kimura, R Dressel, A Fitzner, X Tan, M Linke, U Zechner, W Engel and DV Pantakani. (2015). Dppa3 expression is critical for generation of fully reprogrammed iPS cells and maintenance of Dlk1-Dio3 imprinting. Nat Commun 6:6008.

78. Qian X, JK Kim, W Tong, LG Villa-Diaz and PH Krebsbach. (2016). DPPA5 supports pluripotency and reprogramming by regulating NANOG turnover. Stem Cells 34:588-600.

79. Miharada K, V Sigurdsson and S Karlsson. (2014). Dppa5 improves hematopoietic stem cell activity by reducing endoplasmic reticulum stress. Cell Rep 7:1381-1392.

80. Scotland KB, S Chen, R Sylvester and LJ Gudas. (2009). Analysis of Rex1 (zfp42) function in embryonic stem cell differentiation. Dev Dyn 238:1863-1877.

81. Schopperle WM and WC DeWolf. (2007). The TRA-1-60 and TRA-1-81 human pluripotent stem cell markers are expressed on podocalyxin in embryonal carcinoma. Stem Cells 25:723-730.

82. Teng YD, D Yu, AE Ropper, J Li, S Kabatas, DR Wakeman, J Wang, MP Sullivan, DE Redmond Jr., et al. (2011). Functional multipotency of stem cells: a conceptual review of neurotrophic factor-based evidence and its role in translational research. Curr Neuropharmacol 9:574-585.

83. Yoo MH and DL Hatfield. (2008). The cancer stem cell theory: is it correct? Mol Cells 26:514-516.

84. Thorsson V, DL Gibbs, SD Brown, D Wolf, DS Bortone, TH Ou Yang, E Porta-Pardo, GF Gao, CL Plaisier, et al. (2018). The immune landscape of cancer. Immunity 48 : 812-830.e14.

85. Li Q and BA Barres. (2018). Microglia and macrophages in brain homeostasis and disease. Nat Rev Immunol 18: $225-242$. 
86. Plaks V, N Kong, Z Werb. (2015). The cancer stem cell niche: how essential is the niche in regulating stemness of tumor cells? Cell Stem Cell 16:225-238.

87. Falk S and M Götz. (2017). Glial control of neurogenesis. Curr Opin Neurobiol 47:188-195.

88. Verga Falzacappa MV, C Ronchini, LB Reavie and PG Pelicci. (2012). Regulation of self-renewal in normal and cancer stem cells. FEBS J 279:3559-3572.

89. Zhao JJ, OV Gjoerup, RR Subramanian, Y Cheng, W Chen, TM Roberts and WC Hahn. (2003). Human mammary epithelial cell transformation through the activation of phosphatidylinositol 3-kinase. Cancer Cell 3:483-495.

90. Poleszczuk J, P Hahnfeldt and H Enderling. (2015). Evolution and phenotypic selection of cancer stem cells. PLoS Comput Biol 11:e1004025.

91. Fusi A, S Ochsenreither, A Busse, A Rietz and U Keilholz. (2010). Expression of the stem cell marker nestin in peripheral blood of patients with melanoma. Br J Dermatol 163:107-114.

92. Cherciu I, A Bărbălan, D Pirici, C Mărgăritescu and A Săftoiu. (2014). Stem cells, colorectal cancer and cancer stem cell markers correlations. Health Sci J 40:153-161.

93. Anguille S, VF Van Tendeloo and ZN Berneman. (2012). Leukemia-associated antigens and their relevance to the immunotherapy of acute myeloid leukemia. Leukemia 26: 2186-2196.

94. Meacham CE and SJ Morrison. (2013). Tumour heterogeneity and cancer cell plasticity. Nature 501:328-337.

95. Andrews PW, MM Matin, AR Bahrami, I Damjanov, P Gokhale and JS Draper. (2005). Embryonic stem (ES) cells and embryonal carcinoma (EC) cells: opposite sides of the same coin. Biochem Soc Trans 33:1526-1530.

96. Andrews PW. (1984). Retinoic acid induces neuronal differentiation of a cloned human embryonal carcinoma cell line in vitro. Dev Biol 103:285-293.

97. Trojanowski JQ, JR Mantione, JH Lee, DP Seid, T You, LJ Inge and VM Lee. (1993). Neurons derived from a human teratocarcinoma cell line establish molecular and structural polarity following transplantation into the rodent brain. Exp Neurol 122:283-294.

98. Nelson PT, D Kondziolka, L Wechsler, S Goldstein, J Gebel, S DeCesare, EM Elder, PJ Zhang, A Jacobs, et al. (2002). Clonal human (hNT) neuron grafts for stroke therapy: neuropathology in a patient 27 months after implantation. Am J Pathol 160:1201-1206.

99. Brundin P and A Björklund. (1987). Survival, growth and function of dopaminergic neurons grafted to the brain. Prog Brain Res 71:293-308.

100. Moriarty N, A Pandit and E Dowd. (2017). Encapsulation of primary dopaminergic neurons in a GDNF-loaded collagen hydrogel increases their survival, re-innervation and function after intra-striatal transplantation. Sci Rep 7: 16033.

101. Wertkin AM, RS Turner, SJ Pleasure, TE Golde, SG Younkin, JQ Trojanowski and VM Lee. (1993). Human neurons derived from a teratocarcinoma cell line express solely the 695-amino acid amyloid precursor protein and produce intracellular beta-amyloid or A4 peptides. Proc Natl Acad Sci U S A 90:9513-9517.

102. Roch JM, E Masliah, AC Roch-Levecq, MP Sundsmo, DA Otero, I Veinbergs and T Saitoh. (1994). Increase of synaptic density and memory retention by a peptide representing the trophic domain of the amyloid beta/A4 protein precursor. Proc Natl Acad Sci U S A 91:7450-7454.
103. Ghiso J, A Rostagno, JE Gardella, L Liem, PD Gorevic and B Frangione. (1992). A 109-amino-acid C-terminal fragment of Alzheimer's-disease amyloid precursor protein contains a sequence, -RHDS-, that promotes cell adhesion. Biochem J 288:1053-1059.

104. Koo EH, L Park and DJ Selkoe. (1993). Amyloid betaprotein as a substrate interacts with extracellular matrix to promote neurite outgrowth. Proc Natl Acad Sci U S A 90: 4748-4752.

105. Araki W, N Kitaguchi, Y Tokushima, K Ishii, H Aratake, S Shimohama, S Nakamura and J Kimura. (1991). Trophic effect of beta-amyloid precursor protein on cerebral cortical neurons in culture. Biochem Biophys Res Commun 181:265-271.

106. Milward EA, R Papadopoulos, SJ Fuller, RD Moir, D Small, K Beyreuther and CL Masters. (1992). The amyloid protein precursor of Alzheimer's disease is a mediator of the effects of nerve growth factor on neurite outgrowth. Neuron 9:129-137.

107. Mattson MP, B Cheng, AR Culwell, FS Esch, I Lieberburg and RE Rydel. (1993). Evidence for excitoprotective and intraneuronal calcium-regulating roles for secreted forms of the beta-amyloid precursor protein. Neuron 10:243-254.

108. Schwartz CM, CE Spivak, SC Baker, TK McDaniel, JF Loring, C Nguyen, FJ Chrest, R Wersto, E Arenas, et al. (2005). NTera2: a model system to study dopaminergic differentiation of human embryonic stem cells. Stem Cells Dev 14:517-534.

109. Stern M, A Gierse, S Tan and G Bicker. (2014). Human Ntera2 cells as a predictive in vitro test system for developmental neurotoxicity. Arch Toxicol 88:127-136.

110. Breitbach M, K Kimura, TC Luis, CJ Fuegemann, PS Woll, M Hesse, R Facchini, S Rieck, K Jobin, et al. (2018). In vivo labeling by CD73 marks multipotent stromal cells and highlights endothelial heterogeneity in the bone marrow niche. Cell Stem Cell 22:262-276.e7.

111. Wang Q, J Jiang, G Ying, XQ Xie, X Zhang, W Xu, X Zhang, E Song, H Bu, et al. (2018). Tamoxifen enhances stemness and promotes metastasis of ERalpha36(+) breast cancer by upregulating ALDH1A1 in cancer cells. Cell Res 28:336-358.

112. Bliss SA, S Paul, PW Pobiarzyn, S Ayer, G Sinha, S Pant, H Hilton, N Sharma, MF Cunha, et al. (2018). Evaluation of a developmental hierarchy for breast cancer cells to assess riskbased patient selection for targeted treatment. Sci Rep 8:367.

113. Ropper AE, DK Thakor, I Han, D Yu, X Zeng, JE Anderson, Z Aljuboori, SW Kim, H Wang, et al. (2017). Defining recovery neurobiology of injured spinal cord by synthetic matrix-assisted hMSC implantation. Proc Natl Acad Sci U S A 114:E820-E829.

Address correspondence to: Dr. Yang D. Teng Departments of Physical Medicine and Rehabilitation, and Neurosurgery Harvard Medical School and Spaulding Rehabilitation Hospital Network Brigham and Women's Hospital Massachusetts General Hospital Boston, MA 02115

E-mail: yang_teng@hms.harvard.edu Received for publication June 15, 2018 Accepted after revision August 9, 2018 Prepublished on Liebert Instant Online August 9, 2018 